\title{
Periodontal status, quality of life and newborns' health of pregnant women with
}

\section{arterial hypertension: A cohort study}

\author{
Estado periodontal, qualidade de vida e saúde do recém-nascido de gestantes com hipertensão \\ arterial: Um estudo de coorte
}

Estado periodontal, calidad de vida y salud del recién nacido de mujeres embarazadas con

hipertensión arterial: Un estudio de cohorte

Received: 07/14/2021 | Reviewed: 07/21/2021 | Accept: 07/22/2021 | Published: 07/30/2021

\author{
Gerson Aparecido Foratori-Junior \\ ORCID: https://orcid.org/0000-0003-4760-8948 \\ University of São Paulo, Brazil \\ E-mail: gerson.foratori@usp.br \\ Bruno Gualtieri Jesuino \\ ORCID: https://orcid.org/0000-0003-4456-3713 \\ University of São Paulo, Brazil \\ E-mail: bruno.jesuino@usp.br \\ Silvia Helena de Carvalho Sales-Peres \\ ORCID: https://orcid.org/0000-0003-3811-7899 \\ University of São Paulo, Brazil \\ E-mail: shcperes@usp.br
}

\begin{abstract}
This study aimed to evaluate, both during pregnancy and after delivery, the periodontal status and quality of life of women with gestational hypertension (GH). Secondarily, understanding the relationship between these outcomes and newborns' health. The sample was divided into GH $(\mathrm{G} 1=26)$ and without $\mathrm{GH}(\mathrm{G} 2=26)$ and evaluated regarding: a) contextual variables, b) systemic and periodontal status; and c) newborns' health. ANOVA, Friedman, Cochran's Q test, chi-squared test, and binary logistic regression were conducted $(\mathrm{P}<0.05)$. A higher prevalence of women in $\mathrm{G} 1$ was diagnosed with pre-pregnancy obesity $(\mathrm{P}<0.001)$. A higher prevalence of periodontitis was found in women in $\mathrm{G} 1$ in both periods $(\mathrm{P}<0.001)$. The logistic model revealed that high maternal $\mathrm{BMI}$ (adjusted $\mathrm{OR}=1.28 ; 95 \% \mathrm{CI}=$ $1.10-1.47 ; \mathrm{P}=0.001$ ) was associated with the presence of periodontitis. In both periods, G1 showed worse parameters related to physical pain and disability $(\mathrm{P}<0.001)$, psychological discomfort and disability $(\mathrm{P}<0.001)$. The logistic model revealed that periodontitis (adjusted $\mathrm{OR}=11.64 ; 95 \% \mathrm{CI}=1.18-114.85 ; \mathrm{P}=0.036$ ) was associated with a low quality of life. The groups did not show significant differences in the infants' birth data. GH is associated with obesity and, together, seem to be associated with worsened periodontal parameters and, consequently, negative women's quality of life. Children born to women with GH did not show any health impairment at birth.
\end{abstract}

Keywords: Gestational Hypertension; Obesity; Periodontitis; Quality of Life.

\begin{abstract}
Resumo
Este estudo avaliou, durante a gestação e após o parto, o estado periodontal e a qualidade de vida de mulheres com hipertensão gestacional (HG). Além disso, investigou a relação desses resultados com a saúde dos recém-nascidos. A amostra foi dividida em HG $(\mathrm{G} 1=26)$ e sem $\mathrm{HG}(\mathrm{G} 2=26)$ e avaliada quanto a: a) variáveis contextuais, b) estado sistêmico e periodontal; e c) saúde do recém-nascido. ANOVA, Friedman, Q de Cochran, qui-quadrado e regressão logística binária foram adotados $(\mathrm{P}<0,05)$. Maior prevalência de mulheres no $\mathrm{G} 1$ foi diagnosticada com obesidade pré-gestacional $(\mathrm{P}<0,001)$. Maior prevalência de periodontite foi encontrada nas mulheres do $\mathrm{G} 1 \mathrm{em}$ ambos os períodos $(\mathrm{P}<0,001)$. O modelo logístico revelou que o IMC materno elevado (OR ajustado $=1,28$; IC 95\% $=1,10$ $1,47 ; \mathrm{P}=0,001)$ esteve associado à presença de periodontite. Em ambos os períodos, o G1 apresentou piores parâmetros relacionados à dor e incapacidade física $(\mathrm{P}<0,001)$, incapacidade e desconforto psicológico $(\mathrm{P}<0,001)$. $\mathrm{O}$ modelo logístico revelou que a periodontite (OR ajustado $=11,64$; IC 95\% $=1,18-114,85 ; \mathrm{P}=0,036)$ esteve associada a uma pior qualidade de vida. Os grupos não mostraram diferenças significativas nos dados de nascimento dos bebês. A HG está associada à obesidade e, juntas, parecem estar associadas à piora dos parâmetros periodontais e, consequentemente, à qualidade de vida negativa das mulheres. Crianças nascidas de mulheres com HG não apresentaram qualquer prejuízo de saúde ao nascer.
\end{abstract}

Palavras-chave: Hipertensão Gestacional; Obesidade; Periodontite; Qualidade de Vida. 


\section{Resumen}

Este estudio evaluó, durante el embarazo y después del parto, el estado periodontal y la calidad de vida de mujeres con hipertensión gestacional (HG). Además, investigó la relación de estos resultados con la salud de los recién nacidos. La muestra se dividió en $\mathrm{HG}(\mathrm{G} 1=26)$ y $\sin \mathrm{HG}(\mathrm{G} 2=26)$ y se evaluó para: a) variables contextuales, b) estado sistémico y periodontal; y c) salud del recién nacido. Se adoptaron ANOVA, Friedman, Q de Cochran, chicuadrado y regresión logística binaria $(\mathrm{P}<0,05)$. La mayor prevalencia de mujeres en $\mathrm{G} 1$ fue diagnosticada con obesidad antes del embarazo $(\mathrm{P}<0,001)$. Se encontró mayor prevalencia de periodontitis en mujeres del G1 en ambos períodos $(\mathrm{P}<0,001)$. El modelo logístico reveló que un IMC materno elevado $(\mathrm{OR}$ ajustado $=1,28 ; \mathrm{IC}$ del $95 \%=$ 1,10-1,47; $\mathrm{P}=0,001)$ se asoció con la presencia de periodontitis. En ambos períodos, G1 tuvo peores parámetros relacionados con el dolor y la discapacidad física $(\mathrm{P}<0,001)$, el malestar y la discapacidad psicológica $(\mathrm{P}<0,001)$. El modelo logístico reveló que la periodontitis $(\mathrm{OR}$ ajustado $=11,64 ; \mathrm{IC}$ del 95\% $=1,18-114,85 ; \mathrm{P}=0,036)$ se asoció con una peor calidad de vida. Los grupos no mostraron diferencias significativas en los datos de nacimiento de los bebés. La HG se asocia a la obesidad y, en conjunto, parecen estar associados con el empeoramiento de los parámetros periodontales $\mathrm{y}$, en consecuencia, con la calidad de vida negativa de la mujer. Los niños nacidos de mujeres con HG no mostraron ningún daño a la salud al nacer.

Palabras clave: Hipertensión Gestacional; Obesidad; Periodontitis; Calidad de Vida.

\section{Introduction}

Gestational hypertension is defined as the development of high blood pressure during pregnancy, with values equal to or greater than 140/90 mmHg, normalizing this condition after delivery (Kintiraki, et al., 2015). Studies show higher risks of adverse pregnancy outcomes among women with gestational hypertension compared with those without hypertension, such as abruptio placentae, cerebrovascular events, organ failure, and disseminated intravascular coagulation. In addition, fetuses of these mothers are at greater risk of intrauterine growth retardation, prematurity, and intrauterine death (Berhe, et al., 2019; Kintiraki, et al., 2015).

Currently, scientific evidences have showed the association between arterial hypertension and periodontitis (MartinCabezas, et al., 2016; Muñoz Aguilera, et al., 2020). However, the casual relationship between these outcomes is not clear. Muñoz Aguilera et al. (2020) pointed out that prospective studies have confirmed periodontitis diagnosis increased the likelihood of hypertension occurrence. Nevertheless, the evidence suggesting that periodontitis therapy could reduce blood pressure is inconclusive (Muñoz Aguilera, et al., 2020). Therefore, the cause-and-effect relationship between hypertension and periodontitis is unclear.

Worse periodontal parameters during pregnancy affect the quality of life of individuals (Fakheran, et al., 2020). Similarly, health-related quality of life in individuals with hypertension is worse than that of those without hypertension (Ye, et al., 2018). Caracho et al. (2020) found a higher prevalence of arterial hypertension, worse periodontal conditions, and poor quality of life in overweight pregnant women. However, there is a lack of studies in the literature that prospectively assess the periodontal status and quality of life of sample composed by pregnant women diagnosed by gestational hypertension.

Although gestational hypertension is associated with obesity due to the generalized inflammatory state caused by inflammatory mediators secreted by adipose tissue, studies have shown the antagonistic effects of these outcomes on newborns' health, since obesity is associated with macrosomia (Dai, He \& Hu, 2018) and hypertension is associated with low birth weight (Berhe, et al., 2019). On the other hand, when maternal obesity is associated with periodontitis, infants have been born with low/insufficient weight (Foratori-Junior, et al., 2020b). In addition, although excessive gestational weight gain (GWG) is associated with maternal hypertension, Jesuino et al. (2020) showed that pregnant women with excessive GWG had children with body mass index (BMI) at birth above normal (Jesuino, et al., 2020).

The aim of this study was to evaluate, both during pregnancy and after delivery, the periodontal status and quality of life of women with and without gestational hypertension. Moreover, understanding the relationship between these outcomes and newborns' health. 


\section{Methodology}

This prospective cohort followed the Strengthening the Reporting of Observational Studies in Epidemiology (STROBE).

\section{Ethical aspects}

This study was conducted in compliance with the Declaration of Helsinki and was approved by the Research Ethics Committee (CAAE 58339416.4.0000.5417). All participants provided written informed consent.

\section{Sample composition}

Pregnant women were consecutively recruited from the public health system in the city of Bauru, São Paulo, Brazil, between August/2019 and March/2020. The sample were classified as having hypertension during pregnancy when they had systolic blood pressure (SBP) equals to or higher than $140 \mathrm{mmHg}$ and/or diastolic blood pressure (DBP) equals to or higher than $90 \mathrm{mmHg}$ (Berhe, et al., 2019).

Eligibility criteria were: patients with good cognitive/neuromotor ability, regular gestational follow-up and being in the 3 rd gestational trimester (from the $27^{\text {th }}$ gestational week based on the date of last period). In contrast, pregnant women who required absolute rest, users of alcohol and illicit drugs, smokers, under orthodontic treatment, who were using drugs that could harm the oral condition; diagnosed with gestational diabetes mellitus or anemia during pregnancy; who have undergone fertility treatment; and with a previous history of alveolar bone loss or who had already undergone periodontal treatment were excluded. In addition, it was not included in the sample women who already had pre-pregnancy systemic impairment (diabetes mellitus, arterial hypertension, and anemia).

Sixty-six women were consecutively recruited for this study; nevertheless, 14 women were excluded from the sample for the following reasons: miscarriage $(n=1)$, antibiotic treatment during pregnancy $(n=2)$, started orthodontic treatment after the first evaluation of this study $(n=3)$, and non-attendance without justification after delivery $(n=8)$. Therefore, the sample of this study consisted of 52 pregnant women who were divided into two groups: with hypertension $(\mathrm{G} 1=26)$ and without arterial hypertension $(\mathrm{G} 2=26)$, which were evaluated during the 3rd trimester of pregnancy (T1) and 3 months after delivery (T2) (Figure 1). 
Figure 1. Selection and follow-up methods description.

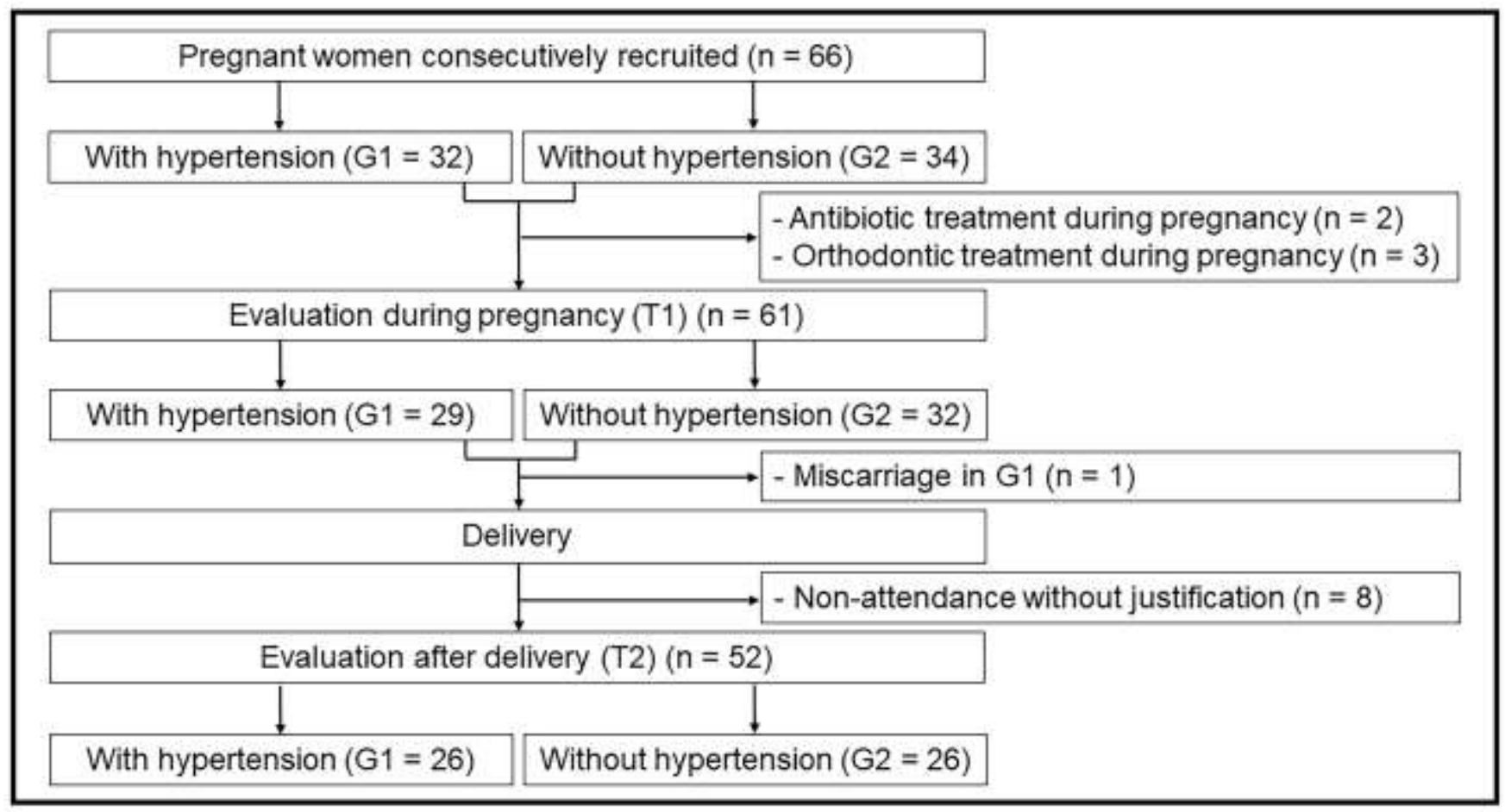

Source: Authors.

\section{Anthropometric parameters}

Pre-pregnancy weight was obtained from the medical file. Women' height was measured using a calibrated stadiometer (Wood 2.20; WCS Ind., Curitiba, Paraná, Brazil). In T1 and T2, the women' weight was also obtained using a calibrated automatic scale (MIC model 300PP, maximum capacity $300 \mathrm{~kg}$; Micheletti Ind., São Paulo, São Paulo, Brazil). Gestational weight gain classification was based on the Institute of Medicine recommendation, which considers women' prepregnancy nutritional status. Excessive gestational weight gain was considered when women with pre-pregnancy normal BMI, overweight and obesity gained higher than 16.0, 11.5 and 9.0 kilograms, respectively, throughout pregnancy (Institute of Medicine, 2009).

\section{Oral evaluation}

Oral examination was performed by one calibrated dentist (Kappa intra-examiner $=0.89$ ) in dental chair with plain oral mirror n. 05 (Cod. 7503; Duflex/SS White, Juiz de Fora, Minas Gerais, Brazil), standard Universal North Carolina periodontal clinical probe (QD.320.05; Quinelato, Schobell Ind. Ltda, Rio Claro, São Paulo, Brazil) and syringe with compressed air. Intra-examiner reliability was assessed based a pilot study with 10 patients, which were not included in the sample of this study. With respect to oral hygiene behavior, women were evaluated in T1 and T2 regarding daily tooth brushing and daily flossing.

Full-mouth periodontal examination was performed with a manual North Carolina-type periodontal probe (QD.320.05; Quinelato, Schobell Ind. Ltda, Rio Claro, São Paulo, Brazil), excluding the third molars. Periodontitis was present if (i) interdental clinical attachment loss (CAL) was observed at two or more non-adjacent teeth, or buccal or oral CAL of $\geq 3$ $\mathrm{mm}$ with probing pocket depth (PPD) of $>3 \mathrm{~mm}$ at two or more teeth. This observed CAL was not ascribed to non-periodontal causes, as described by Tonetti et al. Subsequently, women diagnosed with periodontitis were classified as stages I, II, III, and 
IV of the disease (Tonetti, et al., 2018).

Visible dental biofilm on the buccal and/or lingual surfaces of all teeth was recorded by visible dental biofilm index, and the results were used to calculate the prevalence of dental surfaces with dental plaque. Regarding the bleeding on probing evaluation for each site, the index proposed by Ainamo and Bay (Ainamo \& Bay, 1975) was adopted. The number of positive findings was expressed as a percentage of the total number of probed sites. A patient with an intact periodontium (without clinical attachment loss) was diagnosed as a "case of gingivitis" according to the bleeding on probing score equals to or higher than $10 \%$, being categorized as localized (BOP score $\geq 10 \%$ and $\leq 30 \%$ ) or generalized (BOP score $>30 \%$ ), according to the definition proposed by Trombelli and collaborators (Trombelli, et al., 2018).

\section{Oral Health-related Quality of Life assessment}

Women' oral health-related quality of life was measured during pregnancy (T1) and after delivery (T2) using the short version of the Oral Health Impact Profile questionnaire (OHIP-14), which was applied through a standardized interview to avoid different interpretations among women, minimizing the subjectivity of the questionnaire.

The following dimensions were assessed: functional limitation, physical pain, psychological discomfort, physical disability, psychological disability, social disability, and handicap (Oliveira \& Nadanovsky, 2005) The response codes for all 14 questions were: $0=$ never, $1=$ rarely, 2 = sometimes, $3=$ frequently, $4=$ always. The average between the two questions for each dimension was calculated. The total score (sum of the mean of all dimensions) ranged from 0 to 28 , where the value of zero (0) was classified as "without impact of oral condition on quality of life"; $0<\mathrm{OHIP}-14 \leq 9$ was classified as "low impact"; $9<$ OHIP-14 $\leq 18$ was classified as "medium impact"; and $18<$ OHIP-14 $\leq 28$ was classified as "strong impact" (Caracho, et al., 2020; Foratori-Junior, et al., 2021).

\section{Infants' data at birth}

Infants' weight at birth was classified as follows: low birth weight (LBW) $<2,500 \mathrm{~g}$ (World Health Organization, 2006); Insufficient weight at birth (IWB) $=2,500$ to 2,999 g (World Health Organization, 2006); Normal birth weight (NBW) $=3,000$ to 3,999 g (Rossi \& Vasconcelos, 2010); High birth weight $(\mathrm{HBW})>4,000 \mathrm{~g}$ (Jeanne, et al., 2018). BMI at birth was calculated by dividing the weight by the square of height. Finally, the gestational week in which the children were born was collected. Delivery was considered preterm for children born before the $37^{\text {th }}$ gestational week (World Health Organization, 2006).

\section{Statistical analysis}

IBM SPSS (Released 2017, Version 25.0; IBM Corp., Armonk, NY, USA) was used for statistical analysis. For sample size, the Hosmer and Lemeshow protocol for logistic regression analysis was considered, according to previous studies (Caracho, et al., 2020; Foratori-Junior, et al., 2020b). Moreover, according to previous evidences in the same field (ForatoriJunior, et al., 2020a; Foratori-Junior, et al., 2021; Fusco, et al., 2019; Jesuino, et al., 2020) the power test was calculated considering the difference between the mean of CAL of the groups during pregnancy of at least $10 \%$, with a standard deviation of $10 \%$. Based on the mean CAL and standard deviations of the two groups, an effect size of 0.81 was obtained, resulting in a power of $89 \%$ with the sample size used.

In the bivariate analysis, after Shapiro-Wilk and Bartlett tests were applied, the following tests were considered: ANOVA (\% BOP); Friedman (BMI, daily tooth brushing, daily dental floss using, PPD, CAL, \% dental plaque, functional limitation, physical pain, psychological discomfort, physical disability, psychological disability, social disability, handicap, and 
overall OHIP-14 score); Cochran's Q test (periodontitis classification); and chi-squared (gestational weight gain classification). The Bonferroni test was applied to identify inter-group and inter-period differences.

Binary logistic regression (stepwise backward - likelihood ratio) was performed. According to the standardized statistical criteria, all independent variables with $\mathrm{P}<0.20$ in bivariate analyses were included in the initial model of logistic regression. Hosmer-Lemeshow, collinearity, and residual analyses were implemented to explain the results. A significance level of $5 \%$ was adopted.

\section{Results}

As the groups were paired for age and socioeconomic-cultural status, there were no differences between G1 and G2 for age ( $P=0.520)$, schooling level $(P=0.278)$, or household monthly income $(P=0.216)$. $G 1$ and $G 2$ had an average age of $30.84( \pm 4.93)$ and $29.69( \pm 5.04)$, respectively. All women in the sample finished high school and received four or more minimum wages, respectively.

A higher prevalence $(\approx 30 \%)$ of G1 was classified as having excessive GWG, while only approximately $7 \%(\mathrm{n}=2)$ of G2 showed the same condition $(\mathrm{P}=0.036)$ (Figure 2). In addition, the groups differed in terms of BMI for all periods $(\mathrm{P}<$ 0.001) (Figure 3). The BMI averages for G1 at T0, T1, and T2 were 32.01, 34.83, and 32.17. G2 showed averages of 23.93, 26.58, and 24.91 in the same periods. $23 \%(\mathrm{n}=6), 19 \%(\mathrm{n}=5)$ and $57 \%(\mathrm{n}=15)$ of patients from $\mathrm{G} 1$ were classified as normal BMI, overweight and obesity, respectively. Whilst, 69\% $(\mathrm{n}=18), 23 \%(\mathrm{n}=6)$ and $7 \%(\mathrm{n}=2)$ of patients from $\mathrm{G} 2$ were classified as normal BMI, overweight and obesity.

Figure 2. Comparison of gestational weight gain between groups.

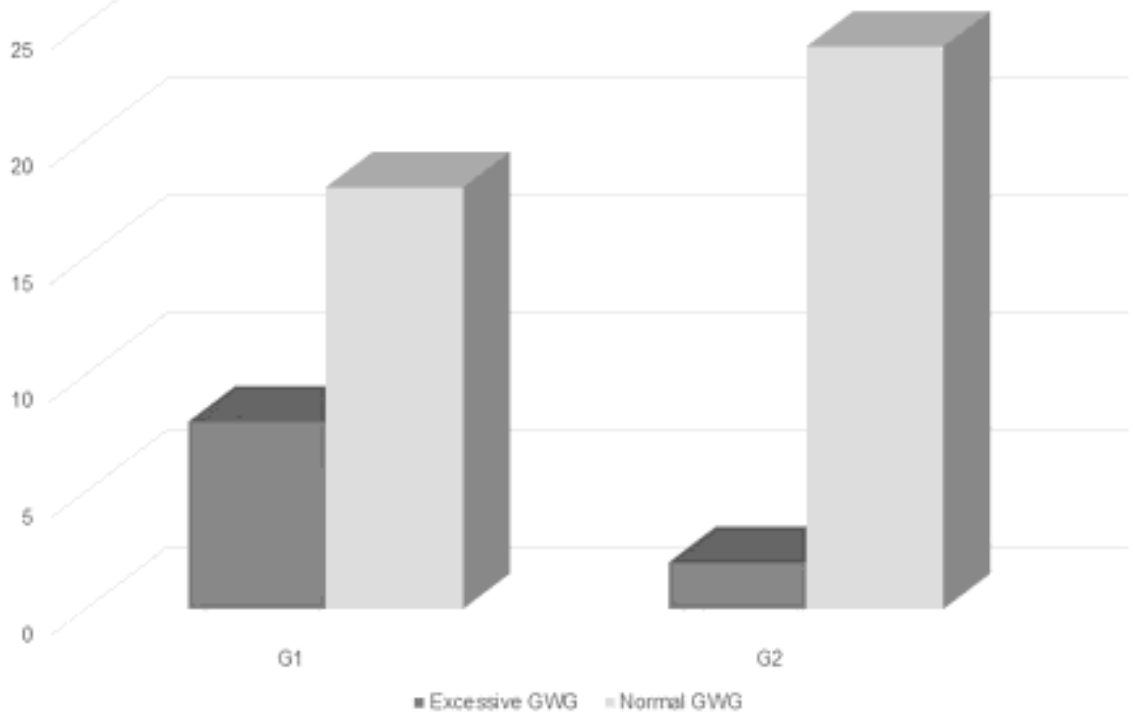

Source: Authors. 
Figure 3. Comparison between groups of BMI values in T0, T1 and T2.

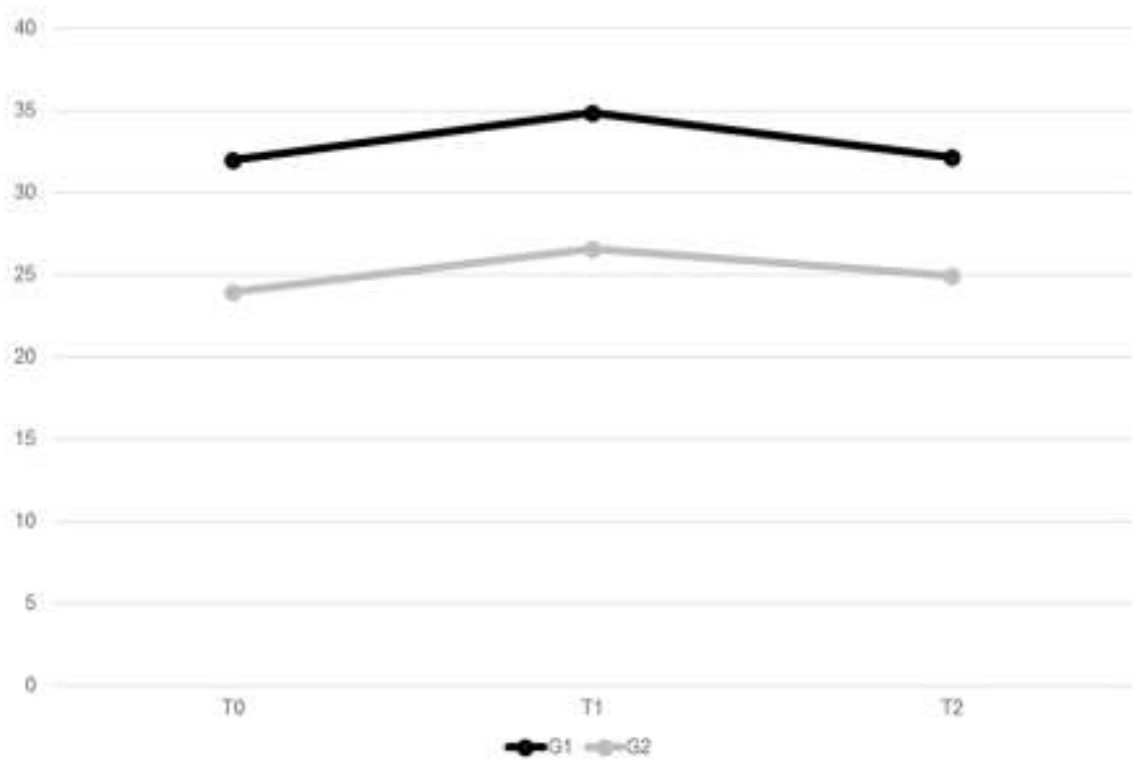

Source: Authors.

G1 showed a lower frequency in daily flossing in T1 and G2, in turn, showed a significant reduction in daily flossing after delivery $(\mathrm{P}=0.004)$. Both groups showed an increase in the prevalence of dental surfaces with plaque after delivery $(\mathrm{P}<$ 0.001). There were no differences in the prevalence of sites with BOP between groups and periods (Table 1).

G1 showed worse PPD values in both periods $(\mathrm{P}=0.001)$ and worse CAL values at $\mathrm{T} 1(\mathrm{P}=0.012)$. Thus, a higher prevalence of periodontitis was found in women in G1 in both periods ( $\mathrm{P}<0.001)$. In T1, 17 women from G1 were diagnosed with periodontitis, of which 5, 8, and 4 were classified as stages I, II, and III of periodontitis, respectively. In T2, 15 w omen in the same group had periodontitis, of which 8,5 , and 2 were categorized as stages I, II, and III of periodontitis, respectively (Table 1). 
Table 1. Comparison of oral hygiene behaviors and periodontal parameters between groups and periods.

\begin{tabular}{|c|c|c|c|c|c|}
\hline & \multicolumn{2}{|c|}{ T1 } & \multicolumn{2}{|c|}{$\mathbf{T} 2$} & \multirow[b]{2}{*}{$\mathbf{P}$} \\
\hline & $\begin{array}{c}\text { G1 }(\mathrm{n}=\mathbf{2 6}) \\
\text { Median } \\
{\left[1^{\text {st }}-3^{\text {rd }} \text { quartiles }\right]}\end{array}$ & $\begin{array}{c}\text { G2 }(\mathrm{n}=\mathbf{2 6}) \\
\text { Median } \\
{\left[1^{\text {st }} \mathbf{3}^{\text {rd }} \text { quartiles }\right]}\end{array}$ & $\begin{array}{c}\text { G1 }(\mathrm{n}=\mathbf{2 6}) \\
\text { Median } \\
{\left[1^{\text {st }}-3^{\text {rd }} \text { quartiles }\right]}\end{array}$ & $\begin{array}{c}\text { G2 }(\mathrm{n}=\mathbf{2 6}) \\
\text { Median } \\
{\left[1^{\text {st }}-3^{\text {rd }} \text { quartiles }\right]}\end{array}$ & \\
\hline Daily toothbrushing & $\begin{array}{c}3 \\
{[3-3]}\end{array}$ & $\begin{array}{c}3 \\
{[3-3]}\end{array}$ & $\begin{array}{c}3 \\
{[2-3]}\end{array}$ & $\begin{array}{c}3 \\
{[2-3]}\end{array}$ & $0.118^{\dagger}$ \\
\hline Daily dental-floss use & $\begin{array}{c}1 \\
{[0-1]} \\
\text { Aa }\end{array}$ & $\begin{array}{c}1 \\
{[1-1]} \\
\mathbf{A b}\end{array}$ & $\begin{array}{c}0 \\
{[0-1]} \\
\mathrm{Aa}\end{array}$ & $\begin{array}{c}0 \\
{[0-1]} \\
\mathbf{B a}\end{array}$ & $\mathbf{0 . 0 0 4} 4^{\dagger}$ \\
\hline Prev. bacterial plaque (\%) & $\begin{array}{c}29.10 \\
{[21.43-60.71]} \\
\text { Aa }\end{array}$ & $\begin{array}{c}17.86 \\
{[7.14-38.46]} \\
\mathbf{A b}\end{array}$ & $\begin{array}{c}55.63 \\
{[37.50-79.17]} \\
\mathbf{B a}\end{array}$ & $\begin{array}{c}60.71 \\
{[39.29-67.86]} \\
\mathbf{B a}\end{array}$ & $<0.001^{\dagger}$ \\
\hline $\mathrm{BOP}(\%)$ & $\begin{array}{c}36.01 \\
{[24.07-47.02]}\end{array}$ & $\begin{array}{c}27.68 \\
{[16.07-41.07]}\end{array}$ & $\begin{array}{c}41.35 \\
{[27.38-50.60]}\end{array}$ & $\begin{array}{c}34.82 \\
{[29.76-51.79]}\end{array}$ & $0.229^{\dagger}$ \\
\hline PPD (mm) & $\begin{array}{c}2.25 \\
{[1.97-2.57]} \\
\text { Aa }\end{array}$ & $\begin{array}{c}1.94 \\
{[1.86-2.10]} \\
\text { Ab }\end{array}$ & $\begin{array}{c}2.10 \\
{[1.98-2.29]} \\
\text { Aa }\end{array}$ & $\begin{array}{c}2.04 \\
{[1.95-2.11]} \\
\text { Ab }\end{array}$ & $\mathbf{0 . 0 0 1} 1^{\dagger}$ \\
\hline CAL (mm) & $\begin{array}{c}2.23 \\
{[2.03-2.41]} \\
\text { Aa }\end{array}$ & $\begin{array}{c}1.98 \\
{[1.86-2.22]} \\
\mathrm{Ab}\end{array}$ & $\begin{array}{c}2.12 \\
{[2.01-2.31]} \\
\mathrm{Aa}\end{array}$ & $\begin{array}{c}2.07 \\
{[1.98-2.14]} \\
\mathrm{Aa}\end{array}$ & $\mathbf{0 . 0 1 2} 2^{\dagger}$ \\
\hline $\begin{array}{c}\text { Stage I } \\
\text { Stage II } \\
\text { Stage III }\end{array}$ & $\begin{array}{c}9 \\
17 \\
\text { Aa } \\
5 \\
8 \\
4\end{array}$ & $\begin{array}{c}20 \\
6 \\
\text { Ab } \\
2 \\
3 \\
1\end{array}$ & $\begin{array}{c}11 \\
15 \\
\text { Aa } \\
8 \\
5 \\
2\end{array}$ & $\begin{array}{c}21 \\
5 \\
\text { Ab } \\
4 \\
1 \\
0\end{array}$ & $<0.001^{*}$ \\
\hline $\begin{array}{r}\text { No } \\
\text { Yes } \\
\text { Localized } \\
\text { Generalized }\end{array}$ & $\begin{array}{l}1 \\
8 \\
5 \\
3\end{array}$ & $\begin{array}{c}6 \\
14 \\
10 \\
4\end{array}$ & $\begin{array}{l}2 \\
9 \\
3 \\
6\end{array}$ & $\begin{array}{c}1 \\
20 \\
5 \\
5\end{array}$ & 0.314 \\
\hline
\end{tabular}

Prev., prevalence; p, significance level; BOP, bleeding on probing; PPD, probing pocket depth; CAL, clinical attachment level ${ }^{\dagger}$ Friedmann test; * Cochran's Q test Post-hoc: Bonferroni test (for all multiple comparisons). Bold values and letters represent statistical differences between groups and/or periods $(\mathrm{P}<0.05)$. Different lowercase letters correspond to differences between groups during the same study assessment period (i.e., T1 or T2). Different capital letters correspond to differences for the same group, between study assessment periods (i.e., T1 and T2). Source: Authors. 
The binary logistic regression model to identify the predictors of periodontitis during pregnancy $(0=$ no periodontitis; 1 = periodontitis) was initially composed of the following variables: maternal BMI, arterial hypertension, gestational weight gain, and the use of daily dental floss (Table 2). All independent variables presented tolerance values higher than 0.60 and variance inflation factor values lower than 2 . The final model was significant $\left[\mathrm{X}^{2}(1)=18.76 ; \mathrm{P}<0.001 ; \mathrm{R}^{2}\right.$ of Nagelkerke $=$ 0.406] and revealed that high maternal BMI (adjusted OR $=1.28 ; 95 \% \mathrm{CI}=1.10-1.47 ; \mathrm{P}=0.001$ ) was associated with the presence of periodontitis during the third trimester of pregnancy. The overall accuracy of the final model was $78.8 \%$. In the Hosmer-Lemeshow analysis, a chi-square value for the final model of 7.57 for 8 degrees of freedom $(\mathrm{P}=0.476)$ was obtained.

Table 2. Binary logistic regression model showing the independent variables related to periodontitis during the third trimester of pregnancy

\begin{tabular}{|c|c|c|c|c|c|}
\hline Model & Variables & B & $\mathbf{P}$ & Adjusted OR & $95 \% \mathrm{CI}$ \\
\hline \multirow{5}{*}{ Model 1} & Hypertension & 0.30 & 0.712 & 1.36 & $0.26-6.96$ \\
\hline & BMI & 0.22 & 0.012 & 1.25 & $1.05-1.50$ \\
\hline & $\begin{array}{l}\text { Gestational weight } \\
\text { gain }\end{array}$ & 1.12 & 0.239 & 3.08 & $0.47-20.10$ \\
\hline & $\begin{array}{l}\text { Daily dental floss } \\
\text { using }\end{array}$ & -0.05 & 0.910 & 0.95 & $0.39-2.27$ \\
\hline & Constant & -6.81 & 0.006 & 0.001 & \\
\hline \multirow{4}{*}{ Model 2} & Hypertension & 0.30 & 0.717 & 1.35 & $0.26-6.89$ \\
\hline & BMI & 0.23 & 0.009 & 1.25 & $1.05-1.49$ \\
\hline & $\begin{array}{l}\text { Gestational weight } \\
\text { gain }\end{array}$ & 1.14 & 0.225 & 3.13 & $0.49-19.90$ \\
\hline & Constant & -6.93 & 0.002 & 0.001 & \\
\hline \multirow{3}{*}{ Model 3} & BMI & 0.24 & 0.001 & 1.28 & $1.10-1.48$ \\
\hline & $\begin{array}{l}\text { Gestational weight } \\
\text { gain }\end{array}$ & 1.24 & 0.166 & 3.46 & $0.59-20.15$ \\
\hline & Constant & -7.26 & 0.001 & 0.001 & \\
\hline \multirow{2}{*}{ Final model } & BMI & 0.24 & 0.001 & 1.28 & $1.10-1.47$ \\
\hline & Constant & -7.01 & $<0.001$ & 0.001 & \\
\hline
\end{tabular}

B: coefficient; P: significance level; Adjusted OR: adjusted odds ratio; CI: confidence interval Source: Authors. 
During pregnancy, G1 showed negative parameters of quality of life and well-being, mainly related to the following dimensions: physical pain $(\mathrm{P}<0.001)$, psychological discomfort $(\mathrm{P}<0.001)$, physical disability $(\mathrm{P}<0.001)$, psychological disability $(\mathrm{P}<0.001)$, and handicap $(\mathrm{P}=0.020)$. All of these dimensions, excluding handicap, were also worst for $\mathrm{G} 1$ in $\mathrm{T} 2$. However, G1 showed an improvement in physical and psychological disability between T1 and T2. With respect to overall OHIP-14 score, G1 had higher overall OHIP-14 scores in T1 and T2, showing an improvement between periods (P < 0.001) (Table 3).

Table 3. Comparison of oral health-related quality of life by OHIP-14 dimensions and overall score periodontal parameters between groups and periods

\begin{tabular}{|c|c|c|c|c|c|}
\hline & \multicolumn{2}{|c|}{ T1 } & \multicolumn{2}{|c|}{$\mathbf{T} 2$} & \multirow[b]{2}{*}{$\mathbf{P}$} \\
\hline & $\begin{array}{c}\text { G1 }(\mathrm{n}=\mathbf{2 6}) \\
\text { Median } \\
{\left[1^{\left.\text {st }-3^{\text {rd }} \text { quartiles }\right]}\right.}\end{array}$ & $\begin{array}{c}\text { G2 }(\mathrm{n}=26) \\
\text { Median } \\
{\left[\mathbf{1}^{\mathrm{st}}-3^{\text {rd }} \text { quartiles }\right]}\end{array}$ & $\begin{array}{c}\text { G1 }(\mathrm{n}=\mathbf{2 6}) \\
\text { Median } \\
{\left[1^{\left.\text {st }-3^{\text {rd }} \text { quartiles }\right]}\right.}\end{array}$ & $\begin{array}{c}\text { G2 }(\mathrm{n}=26) \\
\text { Median } \\
{\left[1^{\text {st }} \mathbf{3}^{\text {rd }} \text { quartiles }\right]}\end{array}$ & \\
\hline Functional limitation & $\begin{array}{c}0[0-1.50] \\
\mathrm{Aa}\end{array}$ & $\begin{array}{c}0[0-1] \\
\text { Aa }\end{array}$ & $\begin{array}{c}0[0-0] \\
\text { Aa }\end{array}$ & $\begin{array}{c}0[0-0] \\
\mathbf{B a}\end{array}$ & $\mathbf{0 . 0 1 6}^{\dagger}$ \\
\hline Physical pain & $\begin{array}{c}2[0-3.50] \\
\text { Aa }\end{array}$ & $\begin{array}{c}0[0-1.50] \\
\mathrm{Ab}\end{array}$ & $\begin{array}{c}1[0-3] \\
\text { Aa }\end{array}$ & $\begin{array}{c}0[0-1] \\
\mathrm{Ab}\end{array}$ & $<0.001^{\dagger}$ \\
\hline $\begin{array}{l}\text { Psychological } \\
\text { discomfort }\end{array}$ & $\begin{array}{c}2[0-3.50] \\
\text { Aa }\end{array}$ & $\begin{array}{c}0.50[0-2] \\
\mathrm{Ab}\end{array}$ & $\begin{array}{c}0.5[0-2.50] \\
\mathrm{Aa}\end{array}$ & $\begin{array}{c}0[0-0.50] \\
\mathrm{Ab}\end{array}$ & $<0.001^{\dagger}$ \\
\hline Physical disability & $\begin{array}{c}0.5[0-3] \\
\mathbf{A a}\end{array}$ & $\begin{array}{c}0[0-0] \\
\mathrm{Ab}\end{array}$ & $\begin{array}{c}0[0-0.50] \\
\mathbf{B a}\end{array}$ & $\begin{array}{c}0[0-0] \\
\mathrm{Ab}\end{array}$ & $<0.001^{\dagger}$ \\
\hline Psychological disability & $\begin{array}{c}0.50[0-2] \\
\mathbf{A a}\end{array}$ & $\begin{array}{c}0[0-0] \\
\mathrm{Ab}\end{array}$ & $\begin{array}{c}0[0-1.50] \\
\mathbf{B a}\end{array}$ & $\begin{array}{c}0[0-0] \\
\mathrm{Ab}\end{array}$ & $<0.001^{\dagger}$ \\
\hline Social disability & $\begin{array}{c}1[0-1.50] \\
\mathrm{Aa}\end{array}$ & $\begin{array}{c}0[0-1.50] \\
\text { Aa }\end{array}$ & $\begin{array}{c}0[0-1] \\
\mathrm{Aa}\end{array}$ & $\begin{array}{c}0[0-0] \\
\text { Aa }\end{array}$ & $0.059^{\dagger}$ \\
\hline Handicap & $\begin{array}{c}0[0-1.50] \\
\text { Aa }\end{array}$ & $\begin{array}{c}0[0-0] \\
\mathrm{Ab}\end{array}$ & $\begin{array}{c}0[0-0] \\
\mathrm{Aa}\end{array}$ & $\begin{array}{c}0[0-0] \\
\mathrm{Aa}\end{array}$ & $\mathbf{0 . 0 2 0}^{\dagger}$ \\
\hline $\begin{array}{l}\text { Overall OHIP-14 score } \\
\text { and categorizations }\end{array}$ & $8[3-12.50]$ & $2[1-6.50]$ & $4[0-9]$ & $0[0-3.50]$ & \\
\hline $\begin{array}{r}\text { No impact } \\
\text { Low }\end{array}$ & $\begin{array}{c}3 \\
13\end{array}$ & $\begin{array}{c}5 \\
19\end{array}$ & $\begin{array}{l}10 \\
11\end{array}$ & $\begin{array}{l}15 \\
10\end{array}$ & $<0.001^{\dagger}$ \\
\hline $\begin{array}{r}\text { Moderate } \\
\text { High }\end{array}$ & $\begin{array}{c}7 \\
3 \\
\mathbf{A a}\end{array}$ & $\begin{array}{r}2 \\
0 \\
\mathrm{Ab}\end{array}$ & $\begin{array}{r}4 \\
1 \\
\mathbf{B a}\end{array}$ & $\begin{array}{c}1 \\
0 \\
\mathrm{Ab}\end{array}$ & \\
\hline
\end{tabular}

P, significance level; ${ }^{\dagger}$ Friedmann test; post-hoc: Bonferroni test (for all multiple comparisons). Bold values and letters represent statistical differences between groups and/or periods $(\mathrm{P}<0.05)$. Different lowercase letters correspond to differences between groups during the same study assessment period (i.e., T1 or T2). Different capital letters correspond to differences for the same group, between study assessment periods (i.e., T1 and T2). Source: Authors. 
The binary logistic regression model to identify the predictors of the low quality of life $(0=$ no/low impact on quality of life; 1 = moderate/high impact on quality of life) was initially composed of the following variables: maternal BMI, arterial hypertension, and presence of periodontitis (Table 4). All independent variables presented tolerance values higher than 0.50, and variance inflation factor values lower than 2 . The final model was significant $\left[\mathrm{X}^{2}(2)=19.97 ; \mathrm{P}<0.001 ; \mathrm{R}^{2}\right.$ of Nagelkerke $=0.483]$ and was composed by high maternal BMI and periodontitis, but only periodontitis during pregnancy (adjusted OR $=$ 11.64; $95 \% \mathrm{CI}=1.18-114.85 ; \mathrm{P}=0.036)$ was associated with a low quality of life. The overall accuracy of the final model was $78.8 \%$. In the Hosmer-Lemeshow analysis, a chi-square value for the final model of 12.64 for eight degrees of freedom (P $=0.125)$ was obtained.

Table 4. Binary logistic regression model showing the independent variables related to moderate/high impact of oral health on quality of life during the third trimester of pregnancy

\begin{tabular}{|c|c|c|c|c|c|}
\hline Model & Variables & B & $\mathbf{P}$ & Adjusted OR & $95 \% \mathrm{CI}$ \\
\hline \multirow{4}{*}{ Model 1} & Hypertension & 0.45 & 0.670 & 1.58 & $0.19-12.99$ \\
\hline & BMI & 0.11 & 0.153 & 1.11 & $0.96-1.30$ \\
\hline & Periodontitis & 2.39 & 0.042 & 10.95 & $1.09-109,51$ \\
\hline & Constant & -6.36 & 0.004 & 0.002 & \\
\hline \multirow{3}{*}{ Final model } & BMI & 0.12 & 0.076 & 1.13 & $0.98-1.30$ \\
\hline & Periodontitis & 2.45 & 0.036 & 11.64 & $1.18-114.85$ \\
\hline & Constant & -6.56 & 0.002 & 0.001 & \\
\hline
\end{tabular}

B: coefficient; P: significance level; Adjusted OR: adjusted odds ratio; CI: confidence interval. Source: Authors.

The groups did not show significant differences in the infants' birth data, such as BMI $(\mathrm{P}=0.568)$, birth size $(\mathrm{P}=$ 0.513), weight $(\mathrm{P}=0.835)$, and weight classification $(\mathrm{P}=0.411)$ as well as infants' birth week $(\mathrm{P}=0.429)($ Table 5). 
Table 5. Comparison between groups of infants' health at birth.

\begin{tabular}{|c|c|c|c|}
\hline & $\begin{array}{c}\text { G1 }(\mathrm{n}=26) \\
\text { Median }\left[1^{\text {st }} 3^{\text {rd }} \text { quartiles }\right] \\
\text { Mean (95\% CI })\end{array}$ & $\begin{array}{c}\text { G2 }(\mathrm{n}=26) \\
\text { Median }\left[1^{\text {st }} 3^{\text {rd }} \text { quartiles }\right] \\
\text { Mean }(95 \% \text { CI })\end{array}$ & $\mathbf{P}$ \\
\hline BMI at birth $\left(\mathrm{kg} / \mathrm{m}^{2}\right)$ & $14.08(13.59-14.56)$ & $13.88(13.36-14.40)$ & $0.568^{\dagger}$ \\
\hline Weight at birth $(\mathrm{kg})$ & $3.32(3.11-3.53)$ & $3.34(3.19-3.50)$ & $0.835^{\dagger}$ \\
\hline Size at birth $(\mathrm{m})$ & $0.490[0.475-0.500]$ & $0.490[0.480-0.505]$ & $0.513 \ddagger$ \\
\hline Gestational birth week & $39[38-40]$ & $39[38-39]$ & 0.429 \\
\hline \multicolumn{4}{|l|}{ Infants' weight at birth } \\
\hline Low/insufficient & 7 & 3 & $0411 \%$ \\
\hline Normal & 16 & 21 & \\
\hline Excessive & 3 & 2 & \\
\hline
\end{tabular}

P, significance level; ${ }^{\dagger}$ t test; ${ }^{\ddagger}$ Mann-Whitney U test.. Source: Authors.

\section{Discussion}

This prospective cohort highlights that gestational hypertension is associated with worsened periodontal parameters and, consequently, negative women's oral health-related quality of life, mainly regarding handicap, physical, and psychological disability. The physical and psychological disability dimensions improved after delivery; nevertheless, the periodontal parameters of women diagnosed with hypertension during pregnancy seem not to improve.

In this study, pregnant women diagnosed with arterial hypertension showed excessive gestational weight gain $(\mathrm{P}=$ 0.036; figure 2) and higher pre-pregnancy BMI when compared with pregnant women without gestational hypertension ( $\mathrm{P}<$ 0.001; figure 3). The hypothesis that explains the association of these outcomes is based on the fact that the individual' adipose tissue secretes inflammatory cytokines, such as TNF-alpha, interleukins, and C-reactive protein, which reduces the host's immune response and causes a generalized state of inflammation in the individuals' body (Foratori-Junior, et al., 2020a; Foratori-Junior, et al ., 2020b). High levels of inflammatory cytokines, in turn, cause vascular inflammation and endothelial disorder (Macedo Paizan \& Vilela-Martin, 2014). In the process of vascular inflammation, there is an increase in vascular permeability, promoting changes in the cytoskeleton of endothelial cells that, consequently, imply endothelial dysfunction, resulting in an imbalance between vasodilation and vasoconstriction. In view of the inflammatory mediators active in this process, vasoconstriction becomes more intense, causing an increase in blood pressure that is clinically diagnosed as hypertension. This mechanism is more evident in pregnancy due to the physiological changes that occur in women during this period, such as higher hormonal levels (Fusco, et al., 2019).

The etiology of hypertension in pregnancy remains unclear (Pralhad, Thomas \& Kushtagi, 2013). Current theories include abnormal placentation (also known as placenta accrete), cardiovascular maladjustment to pregnancy, genetic and immunological mechanisms, increased systemic inflammatory response, and nutritional, hormonal, and angiogenic factors (Pralhad, Thomas \& Kushtagi, 2013). It seems likely, however, that multiple factors are involved. It is suggested, therefore, that inflammation may have a fundamental role in the hypertension's cause during pregnancy or its manifestations (Pralhad, Thomas \& Kushtagi, 2013).

In view of the influence of individual and behavioral factors on the prevalence and evolution of arterial hypertension 
(Antignac, et al., 2018), this study paired the sample according to age and socioeconomic level in order to avoid bias in the interpretation of our outcomes. Therefore, no intergroup differences were found with respect to age $(\mathrm{P}=0.520)$, schooling level $(\mathrm{P}=0.278)$, and household monthly income $(\mathrm{P}=0.216)$.

Regarding periodontal parameters, G1 showed worse PPD values in T1 and T2 $(\mathrm{P}=0.001)$ and worse CAL values at T1 $(\mathrm{P}=0.012)$. A higher prevalence of periodontitis was found in women in $\mathrm{G} 1$ in both periods $(\mathrm{P}<0.001)$. The hypothesis that best explains these findings is based on oral hygiene behavioral habits and changes in the systemic inflammatory profile. G1 showed a lower frequency of daily flossing in T1, while G2 showed a significant worsening in daily flossing after delivery $(\mathrm{P}=0.004)$. Both groups showed an increase in the prevalence of visible dental biofilm after delivery $(\mathrm{P}<0.001)($ Table 1$)$, possibly due to the fact that, after childbirth, the new routine is characterized by a greater time demand for baby care, and there is a negative impact on the quantity and/or quality of oral hygiene (Foratori-Junior, et al., 2020a; Jesuino, et al., 2020). In this study, there were no differences between periods for the prevalence of periodontitis in both groups. However, a small reduction in the prevalence of periodontitis was noted for women in both groups. In addition, when periodontitis was present, the stages were slightly less severe at T2 compared to T1. This can be explained by the fact that all patients with periodontitis, regardless of the groups, underwent supportive periodontal therapy in the third trimester of pregnancy, in accordance with ethical requirements.

Previous studies have pointed out that hypertension in pregnancy is associated with excessive BMI, which in turn, negatively impacts women' periodontal condition because both the high hormonal levels of pregnancy and the inflammatory mediators secreted by the adipose tissue cause exacerbated inflammation in the periodontal tissues (Caracho, et al., 2020; Foratori-Junior, et al., 2020a; Foratori-Junior, et al., 2020b; Foratori-Junior, et al., 2021; Fusco, et al., 2019; Lee, et al., 2014; Jesuino, et al., 2020). In this study, the final logistic regression model revealed that high maternal BMI was associated with the presence of periodontitis during the third trimester of pregnancy (Table 2), pointing out that women with excessive BMI are $28 \%$ more likely to develop periodontitis.

Oral changes resulting from systemic arterial hypertension have a negative impact on individuals' quality of life (Rebelo, et al., 2016). During pregnancy, these outcomes were poorly investigated, but the associations found in this study show similar results. Pregnant women with arterial hypertension diagnosis showed worse parameters of quality of life and well-being, mainly related to physical pain, psychological discomfort, physical disability, psychological disability, and handicap (Table 3). All of these dimensions, excluding handicap, were also worse for G1 even after delivery. G1 had higher overall OHIP-14 scores in T1 and T2, showing an improvement between periods $(\mathrm{P}<0.001)$.

After delivery, G1 showed improvement in the total OHIP-14 score and physical and psychological disability dimensions. The final binary logistic regression model revealed that the presence of periodontitis during pregnancy was associated with a low quality of life (Table 4). However, this result must be interpreted with caution, as the confidence interval was very large, probably due to the sample size of the present study, which is considered a limitation. Previous studies have highlighted the worst quality of life associated with periodontitis in women during pregnancy (Geevarghese, Baskaradoss \& Sarma, 2017; Shah, Batra \& Qureshi, 2017). More recently, Foratori-Junior et al. (2021) showed that women with obesity present higher prevalence of hypertension and also a more negative impact on functional limitation, physical disability, and handicap (Foratori-Junior, et al., 2021). There is still a gap in the literature of prospective studies that sought to assess the periodontal condition and quality of life of women during pregnancy and after childbirth, taking into account the high prevalence of arterial hypertension.

There is controversy in the literature regarding the association of maternal hypertension, gestational excessive weight, maternal periodontitis, and newborn health. As mentioned, excessive maternal BMI is associated with a high prevalence of 
arterial hypertension, and studies show a positive association between excessive weight and periodontal impairment during pregnancy (Caracho, et al., 2020; Foratori-Junior, et al., 2020a; Foratori-Junior, et al., 2020b; Foratori-Junior, et al., 2021; Fusco, et al., 2019; Lee, et al., 2014; Jesuino, et al., 2020), and a positive association between obesity and birth of babies with macrosomia (Ijäs, et al., 2019). In contrast, there is scientific evidence that periodontitis during pregnancy is associated with premature rupture of membranes and, consequently, premature birth and child low birth weight (Manrique-Corredor, et al., 2019) due to periodontopathogenic bacteria that, when they fall into the bloodstream, can lodge in the placenta and cause impairment in the availability of nutrients to fetuses and cause a local inflammatory process that results in early contractions.

In this study, there were no differences between the groups regarding the infants' health parameters at birth (Table 5). However, we emphasize that Foratori-Junior et al. (2020b) showed in a cross-sectional study that women with excessive weight and precarious periodontal conditions are more likely to have underweight babies (Foratori-Junior, et al., 2020b). On the other hand, Jesuino et al. (2020) in a longitudinal study found a high prevalence of arterial hypertension in women with excessive weight gain during pregnancy as well as worse periodontal parameters; however, they were more likely to have babies with high BMI at birth (Jesuino, et al., 2020). It is not clear, therefore, the consequences that gestational hypertension can cause on the health of newborns. Future prospective cohorts with a large sample size should be conducted, controlling for confounding factors, such as excess weight, to better understand the association of these outcomes.

This study has some limitations. Ideally, women diagnosed with systemic arterial hypertension during pregnancy and who are not overweight should be selected, so that it is possible to better understand only the influence of arterial hypertension induced by pregnancy in the periodontal condition. In addition, it would be extremely important to develop prospective cohorts with a larger sample and evaluating the same results from this study since the second trimester of pregnancy and in the long term after delivery. In this study, the presence of gestational hypertension was accessed through medical files; therefore, it refers to a dichotomous variable, with no continuous measurements for the patients' systolic and diastolic pressure. This study did not access the previous history of other pregnancies in the sample. Data referring to systemic and oral changes and about the baby's health history at birth from previous pregnancies could bring new interpretations to our results. Future studies should perform biological tests in saliva and plasma samples to better understand the associations between systemic and periodontal changes.

\section{Final Considerations}

Despite these limitations, this study concluded that gestational hypertension is associated with obesity and, together, seem to be associated with worsened periodontal parameters and, consequently, negative women's quality of life, mainly regarding handicap, physical, and psychological disability. The physical and psychological disability dimensions improved after delivery, but periodontal parameters of women diagnosed with hypertension during pregnancy did not seem to improve. Children born to women with gestational hypertension did not show any health changes at birth.

\section{Acknowledgments}

The authors thank the Coordination of Superior Level Staff Improvement (CAPES - financial code 001) and the São Paulo Research Foundation (FAPESP - grant \#2018/25934-0; grant \#2018/20626-5 and grant \#2019/17640-9) for financially support this study. CAPES and FAPESP had no role in the study design, data analysis, or manuscript drafting/approval. 


\section{References}

Ainamo, J., \& Bay, I. (1975). Problems and proposals for recording gingivitis and plaque. Int Dent J, 25(4), $229-235$.

Antignac, M., Diop, I. B., Macquart de Terline, D., Kramoh, K. E., Balde, D. M., Dzudie, A., Ferreira, B., Houenassi, M. D., Hounsou, D., Ikama, M. S., Kane, A., Kimbally-Kaki, S. G., Kingue, S., Kouam, C. K., Limbole, E., Kuate, L. M., Mipinda, J. B., N'Guetta, R., Nhavoto, C., Sesso, Z., Ali, A. S., Toure, I. A., Plouin, P. F., Perier, M. C., Narayanan, K., Empana, J. P., \& Jouven, X. (2018). Socioeconomic Status and Hypertension Control in Sub-Saharan Africa: The Multination EIGHT Study (Evaluation of Hypertension in Sub-Saharan Africa). Hypertension, 71(4), 577-584. https://doi.org/10.1161/HYPERTENSIONAHA.117.10512.

Berhe, A. K., Ilesanmi, A. O., Aimakhu, C. O., \& Mulugeta, A. (2019). Effect of pregnancy induced hypertension on adverse perinatal outcomes in Tigray regional state, Ethiopia: a prospective cohort study. BMC Pregnancy Childbirth, 20(1), 7. https://doi.org/10.1186/s12884-019-2708-6

Caracho, R. A., Foratori-Junior, G. A., Fusco, N. D. S., Jesuino, B. G., Missio, A. L. T., \& Sales-Peres, S. H. C. (2020). Systemic conditions and oral healthrelated quality of life of pregnant women of normal weight and who are overweight. Int Dent J, 70(4), 287-295. https://doi.org/10.1111/idj.12547.

Dai, R. X., He, X. J., \& Hu, C. L. (2018). Maternal pre-pregnancy obesity and the risk of macrosomia: a meta-analysis. Arch Gynecol Obstet, 297(1), 139-145 https://doi.org/10.1007/s00404-017-4573-8.

Fakheran, O., Saied-Moallemi, Z., Khademi, A., \& Sahebkar, A. (2020). Oral Health-Related Quality of Life during Pregnancy: A Systematic Review. Curr Pharm Des, 26(32), 4014-4021. https://doi.org/10.2174/1381612826666200523171639.

Foratori-Junior, G. A., da Silva, B. M., da Silva Pinto, A. C., Honório, H. M., Groppo, F. C., \& Sales-Peres, S. H. C. (2020a). Systemic and periodontal conditions of overweight/obese patients during pregnancy and after delivery: a prospective cohort. Clin Oral Investig, 24(1), 157-165. https://doi.org/10.1007/s00784-019-02932-x.

Foratori-Junior, G. A., Jesuino, B. G., Caracho, R. A., Orenha, E. S., Groppo, F. C., \& Sales-Peres, S. H. C. (2020b). Association between excessive maternal weight, periodontitis during the third trimester of pregnancy, and infants' health at birth. J Appl Oral Sci, 28, e20190351. https://doi.org/ 10.1590/1678-77572019-0351.

Foratori-Junior, G. A., Missio, A. L. T., Orenha, E. S., \& Sales-Peres, S. H. C. (2021). Systemic Condition, Periodontal Status, and Quality of Life in Obese Women During Pregnancy and After Delivery. Int Dent J. https://doi.org/10.1016/j.identj.2020.12.012.

Fusco, N. D. S., Foratori-Junior, G. A., Missio, A.L.T., Jesuino, B. G., \& Sales-Peres, S. H. C. (2019). Systemic and oral conditions of pregnant women with excessive weight assisted in a private health system. Int Dent J, 69(6), 472-479. https://doi.org/10.1111/idj.12507.

Geevarghese, A., Baskaradoss, J. K., \& Sarma, P. S. (2017). Oral Health-Related Quality of Life and Periodontal Status of Pregnant Women. Matern Child Health J, 21(8), 1634-1642. https://doi.org/10.1007/s10995-016-2255-y.

Ijäs, H., Koivunen, S., Raudaskoski, T., Kajantie, E., Gissler, M., \& Vääräsmäki, M. (2019). Independent and concomitant associations of gestational diabetes and maternal obesity to perinatal outcome: A register-based study. PLoS One, 14(8), e0221549. https://doi.org/10.1371/journal.pone.0221549.

Institute of Medicine (US) and National Research Council (US) Committee to Reexamine IOM Pregnancy Weight Guidelines, Rasmussen, K. M., \& Yaktine, A. L. (2009). Weight Gain During Pregnancy: Reexamining the Guidelines.

Jeanne, T. L., Hooker, E. R., Nguyen, T., Messer, L. C., Sacks, R. M., Andrea, S. B., \& Boone-Heinonen, J. (2018). High birth weight modifies association between adolescent physical activity and cardiometabolic health in women and not men. Prev Med, 108, 29-35. https://doi.org/10.1016/j.ypmed.2017.12.015.

Jesuino, B. G., Foratori-Junior, G. A., Missio, A. L. T., Mascoli, L. S., \& Sales-Peres, S. H. C. (2020). Periodontal status of women with excessive gestational weight gain and the association with their newborns' health. Int Dent J, 70(5), 396-404. https://doi.org/10.1111/idj.12580.

Kintiraki, E., Papakatsika, S., Kotronis, G., Goulis, D. G., \& Kotsis, V. (2015). Pregnancy-Induced hypertension. Hormones (Athens), 14(2), 211-223. https://doi.org/10.14310/horm.2002.1582.

Lee, H. J., Jun, J. K., Lee, S. M., Ha, J. E., Paik, D. I., \& Bae, K. H. (2014). Association between obesity and periodontitis in pregnant females. J Periodontol, 85(7), e224-e231. https://doi.org/10.1902/jop.2014.130578.

Macedo Paizan, M. L., \& Vilela-Martin, J. F. (2014). Is there an association between periodontitis and hypertension? Curr Cardiol Rev, 10(4), 355-361. https://doi.org/10.2174/1573403x10666140416094901.

Manrique-Corredor, E. J., Orozco-Beltran, D., Lopez-Pineda, A., Quesada, J. A., Gil-Guillen, V. F., \& Carratala-Munuera, C. (2019). Maternal periodontitis and preterm birth: Systematic review and meta-analysis. Community Dent Oral Epidemiol, 47(3), 243-251. https://doi.org/10.1111/cdoe.12450.

Martin-Cabezas, R., Seelam, N., Petit, C., Agossa, K., Gaertner, S., Tenenbaum, H., Davideau, J. L., \& Huck, O. (2016). Association between periodontitis and arterial hypertension: A systematic review and meta-analysis. Am Heart J, 180, 98-112. https://doi.org/10.1016/j.ahj.2016.07.018.

Muñoz Aguilera, E., Suvan, J., Buti, J., Czesnikiewicz-Guzik, M., Ribeiro, A. B., Orlandi, M., Guzik, T. J., Hingorani, A. D., Nart, J., \& D’Aiuto, F. (2020). Periodontitis is associated with hypertension: a systematic review and meta-analysis. Cardiovasc Res, 116(1), 28-39. https://doi.org/10.1093/cvr/cvz201.

Oliveira, B. H., \& Nadanovsky, P. (2005). Psychometric properties of the Brazilian version of the Oral Health Impact Profile-short form. Community Dent Oral Epidemiol, 33(4), 307-314. https://doi.org/10.1111/j.1600-0528.2005.00225.x.

Pralhad, S., Thomas, B., \& Kushtagi, P. (2013). Periodontal disease and pregnancy hypertension: a clinical correlation. J Periodontol, 84(8), 1118-1125. https://doi.org/10.1902/jop.2012.120264. 
Research, Society and Development, v. 10, n. 9, e44410918251, 2021

(CC BY 4.0) | ISSN 2525-3409 | DOI: http://dx.doi.org/10.33448/rsd-v10i9.18251

Rebelo, M. A. B., de Castro, P. H. D., Vieira, J. M. R., Robinson, P. G., \& Vettore, M. V. (2016). Low Social Position, Periodontal Disease, and Poor Oral Health-Related Quality of Life in Adults With Systemic Arterial Hypertension. J Periodontol, 87(12), 1379-1387. https://doi.org/10.1902/jop.2016.160204.

Rossi, C. E., \& Vasconcelos, F. A .G. (2010). Birth weight and obesity in children and adolescents: A systematic review. Rev Bras Epidemiol, $13(2), 1-13$.

Shah, A. F., Batra, M., \& Qureshi, A. (2017). Evaluation of Impact of Pregnancy on Oral Health Status and Oral Health Related Quality of Life among Women of Kashmir Valley. J Clin Diagn Res, 11(5), ZC01-ZC04. https://doi.org/10.7860/JCDR/2017/25862.9769.

Tonetti, M. S., Greenwell, H., \& Kornman, K. S. (2018). Staging and grading of periodontitis: Framework and proposal of a new classification and case definition. J Clin Periodontol, 20, S149-S161. https://doi.org/10.1111/jcpe.12945.

Trombelli, L., Farina, R., Silva, C. O., \& Tatakis, D. N. (2018). Plaque-induced gingivitis: Case definition and diagnostic considerations. J Clin Periodontol, 20, S44-S67. https://doi.org/10.1111/jcpe.12939.

World Health Organization. (2006). WHO child growth standards: length/height-for-age, weight-for-age, weight-for-length, weight-for-height and body mass index-for-age: methods and development.

Ye, R., Liu, K., Zhang, Z., Gong, S., \& Chen, X. (2018). Health-related quality of life of hypertension in China: a systematic review and meta-analysis. $J$ Cardiovasc Med (Hagerstown), 19(8), 430-438. https://doi.org/10.2459/JCM.0000000000000678. 